\title{
Mineral chemistry of eclogites to investigate the evolutionary metamorphic history of UHP rocks from Tso-Morari region, Ladakh, India
}

\author{
*D. Rameshwar Rao and Hakim Rai \\ Wadia Institute of Himalayan Geology \\ 33 General Mahadeo Singh Road, Dehradun - 248 001, Uttarakhand, India \\ (*Email: raodr@wihg.res.in)
}

\begin{abstract}
Micro textures of metabasics from the Tso-Morari region, Ladakh were studied in order to understand the evolutionary metamorphic history of eclogites. The mineral chemistry, paragenesis of mineral inclusions in garnet, and zoning in omphacite, garnet and amphibole suggest three main metamorphic stages: (i) an eclogite stage with late blueschist facies metamorphism, (ii) a medium-pressure amphibolite facies stage, and (iii) a low-pressure amphibolite to greenschist facies stage. The high Si content in phengite, presence of rutile besides almandine-rich garnet and omphacite in eclogites indicate the attainment of high pressures. Also, the textural features and composition of amphiboles indicate that blueschist facies conditions represented by growth of glaucophane at high pressure and low temperature were followed by a lower-pressure stage of metamorphism represented by partial and in some cases complete reaction of glaucophane to calcic green amphibole such as magnesio-hornblende. The relationships define a clock-wise P-T path with the involvement of an isothermal uplift path for the eclogites and associated garnet-amphibolites of Tso-Morari region.
\end{abstract}

Keywords: Eclogites, garnet amphibolites, mineral zoning, clock-wise P-T path, isothermal uplift path, Tso-Morari region, Ladakh

Received: December 22, 2009

Revision accepted: May 10, 2010

\section{INTRODUCTION}

A common feature of many eclogites is the association of anhydrous assemblage with hydrous silicates, some of which have clearly secondary alteration products occurring in textural equilibrium with anhydrous eclogite minerals like omphacite and garnet. Commonly, mineral grains of complex composition show chemical zoning from the interior to exterior, which may be used to tell the direction of change of composition with changing time (Schliestedt 1990). There are situations where such zoning reflects changes in chemical and/or physical conditions or with changing metamorphic conditions resulting due to different metamorphic events (Robinson et al. 1982). Careful micro textural observation of secondary minerals replacing garnet and omphacite give important information on the uplift metamorphic history. Mineral inclusions in garnets further provide an opportunity to investigate the evolution of eclogites. Such garnets can be a useful tool in determining the reactions which produced the eclogite paragenesis. The bulk rock compositions of eclogite protoliths also form an important factor in controlling the compositions of both pyroxenes and garnets during high pressure metamorphism.

In this paper, we deal with the eclogites from Tso-Morari region, Ladakh, their mineral chemistry, zoning in minerals, and mineral inclusion studies in garnet to understand their uplift metamorphic history. However, the evidence for the nature of eclogite protoliths and their relationship to the country rock has been reviewed elsewhere (Rameshwar Rao and Rai 2006).

\section{FIELD RELATIONS}

The Tso-Morari Crystalline Complex is divided into two main lithological units (Fig. 1), the low-grade Taglang La Formation to the south and medium to high-grade Puga Formation to the north (Thakur and Misra 1984). The Puga Formation is dominated by the quartzo-feldspathic Puga gneisses. The gneisses and the Polokongka La granite found in this formation have been dated as $\sim 480 \mathrm{Ma}$ (Girard and Bussy 1999; Rameshwar Rao and Rai 2002; Islam et al. 2006). The Puga Formation contains metabasic rocks as lenses along with schists and marbles. Some of the metabasic bodies have suffered eclogite-facies metamorphism (de Sigoyer et al. 1997, 2000; Guillot et al. 1997; Sachan et al. 1999; Jain et al. 2003; Singh and Verma 2006), with ultrahigh pressure minerals like coesite from eclogites of the TsoMorari region (Mukherjee and Sachan 2001). Much work has been carried out on the pressure-temperature conditions of the rocks of this formation (Sachan et al. 1999; de Sigoyer et al. 2000; Jain et al. 2003). 


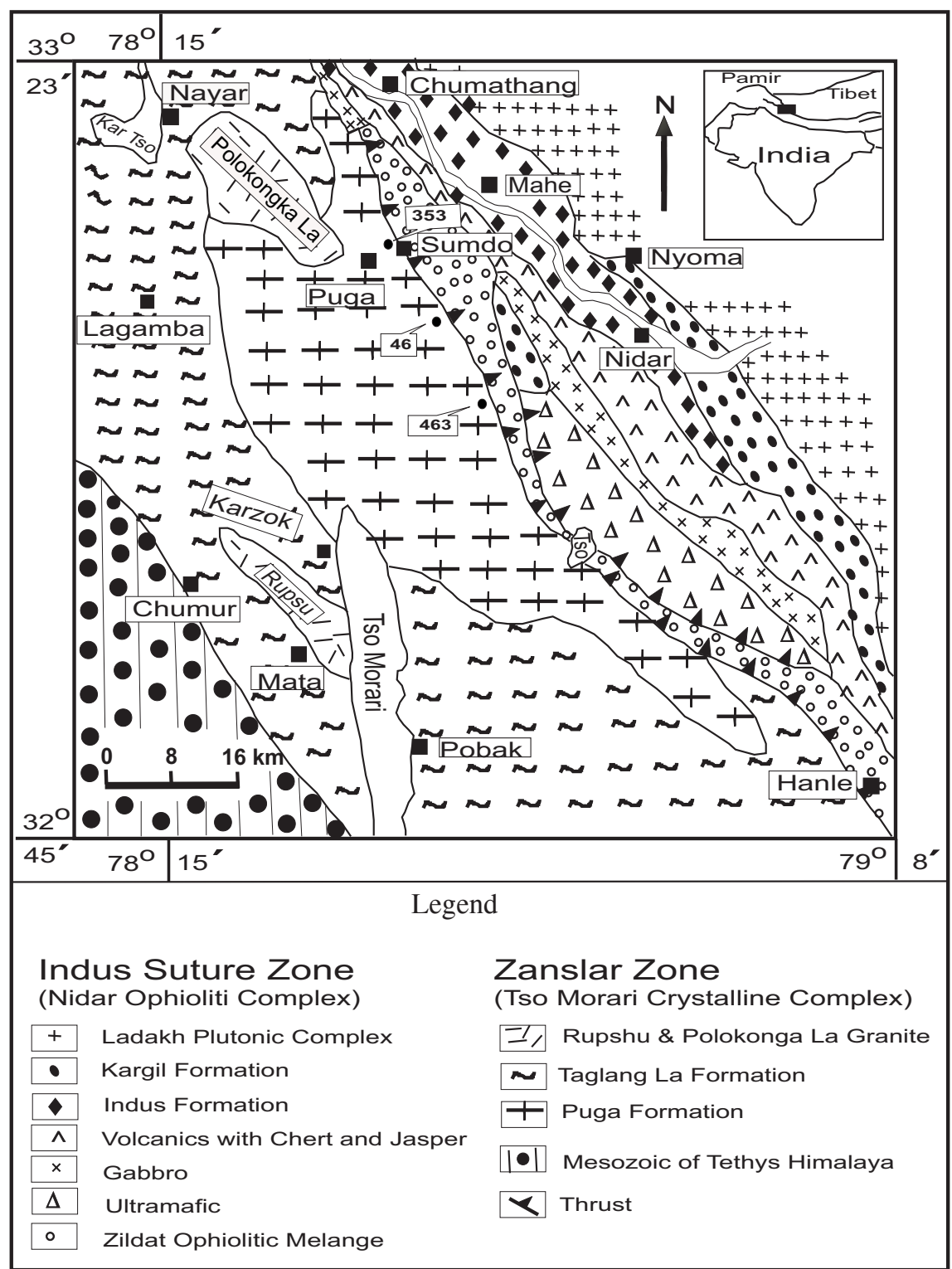

Fig. 1: Geological map of Tso-Morari region, Ladakh, India (after Thakur and Misra 1984). The sample locations of eclogite samples $(46,353,463)$ are also shown on the map.

The eclogites and the associated garnet-amphibolites are the most abundant and widespread mafic rock types of the Tso-Morari Crystalline Complex. It is observed that the lenses of eclogites have rims comprising of retrograde garnetamphibolites. This corroborates the textural features of eclogites, which indicate that some amphibolites are formed by retrograde recrystallization of pre-existing eclogites (Rameshwar Rao and Rai 2006).

\section{MINERALOGY OF ECLOGITES}

Depending on the grain size and degree of retrogression, the rocks under study contain abundant eclogite stage minerals such as garnet, omphacite, glaucophane, clinozoisite and rutile. Additional phases in eclogites are white micas, the paragonite and phengite mica (identified based on EPMA analysis), Fe-Mg chlorite, amphibole, dolomite, kyanite and biotite. Quartz is rarely present as a primary phase, whereas ilmenite, magnetite, zircon, titanite are common accessory phases.

The mineral analyses were carried out on the SX100 CAMECA Electron Probe Micro Analyzer (EPMA) at Wadia Institute of Himalayan Geology, Dehradun, India under comparable operating conditions of $15 \mathrm{keV}$ accelerating voltage, $20 \mathrm{nA}$ beam current, $1 \mathrm{~mm}$ beam size. The PAP correction programme applied to mineral data is after Pouchou and Pichoir (1985). The EPMA analyses of matrix minerals are given in Table 1, the zoned garnet analyses in 
Mineral chemistry of eclogites to investigate the evolutionary metamorphic history

Table 1: EPMA data of matrix mineral assemblage in eclogites from Tso-Morari region, Ladakh

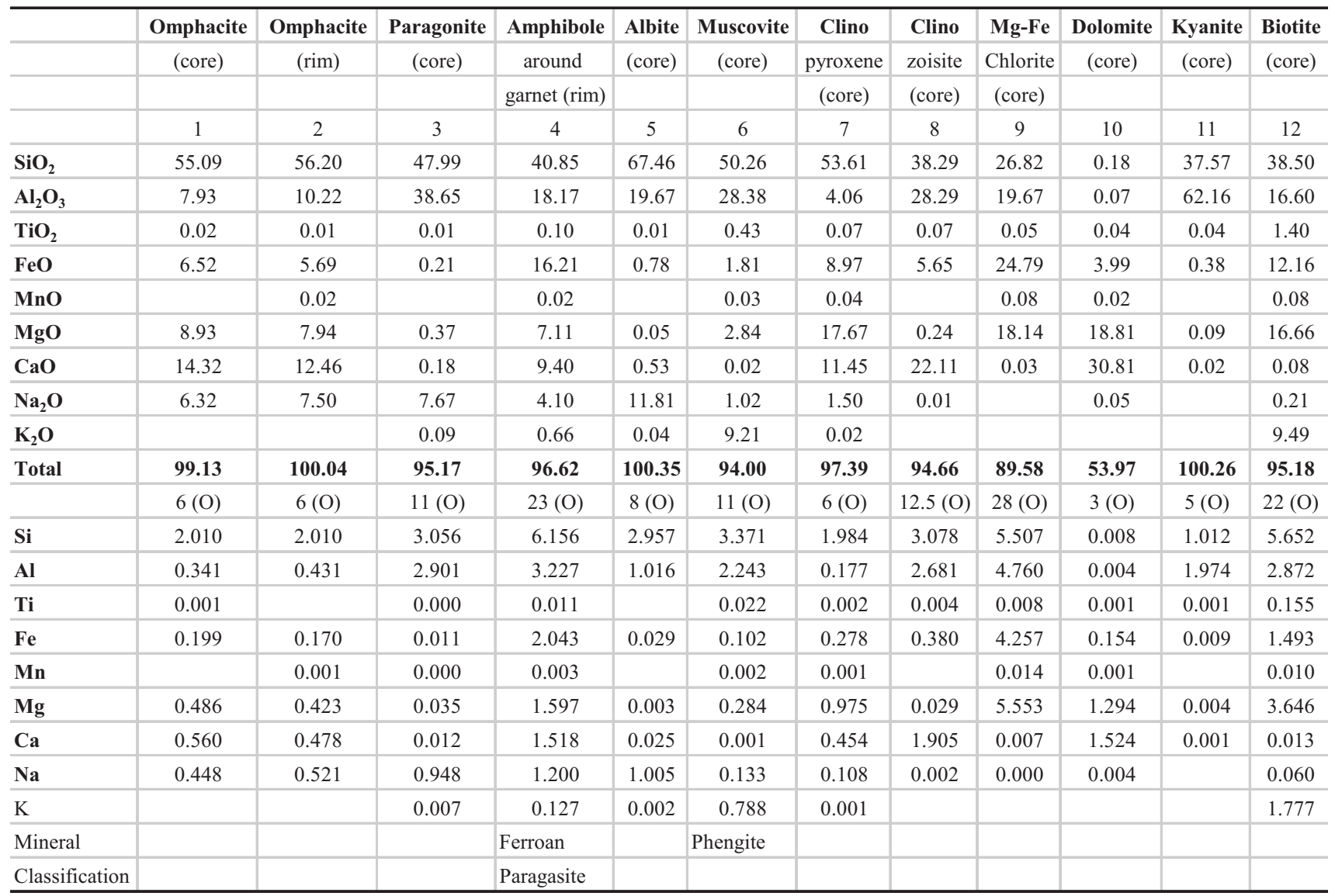

Note: The composition of garnet and amphibole along with zoning from core to rim are shown in Tables 2 and 3 respectively.

Table 2, zoned amphibole analyses in Table 3, and the analyses of mineral inclusions in garnet are given in Table 4 . The splitting of $\mathrm{FeO}$ and $\mathrm{Fe}_{2} \mathrm{O}_{3}$, the stoichiometry calculations and Leake's classification of amphiboles given in Table 3 are based on the software Rameshwar Rao and Subba Rao (1996).

Garnets are anhedral and subrounded porphyroblasts in these rocks, and they tend to be fractured. They are almandine rich and show conspicuous compositional zoning. Garnet core has high $\mathrm{Mn}$ and $\mathrm{Fe} / \mathrm{Mg}$ (Table 2), their $\mathrm{X}_{\mathrm{Fe}}$ ranges from 0.64 from core to 0.59 towards rim (Table 2). They host a large number of primary and secondary inclusions like dark green amphibole, omphacite, paragonite, magnetite, ilmenite, apatite, rutile, dolomite (Table 4, Figs. 2a-c). However, no inclusions of $\mathrm{Na}$-amphibole, glaucophane are observed. The inclusions are found to spread through out the garnet porphyroblasts (Fig. 2a), with inclusions such as paragonite, ilmenite, rutile, magnetite are also observed in the coremantle, while omphacite, quartz, amphibole and other inclusions are found mostly in mantle. Secondary epidote and amphibole are found to replace garnet around rim and along cracks. The distributions of inclusions in garnet suggest the zoning in garnet was probably controlled by reactions taking place during the growth of the garnet, interpreted to be as growth zoning (Krogh 1980; 1982).

The pyroxene in these rocks is dominantly omphacite. Clinopyroxene with other variable composition are present in matrix as symplectic textures, probably suggesting their earlier existence as protoliths. Omphacite shows compositional zoning with conspicuous increase in $\mathrm{Al}$ and $\mathrm{Na}$ and decrease of $\mathrm{Mg}$ and Fe from core to rim (Table 1). Amphiboles in these eclogites form either isolated crystals along with the eclogite paragenesis or poikiloblasts on garnet and omphacite. Three optically and chemically distinct amphiboles namely glaucophane, barroisite and blue-green amphibole coexist in our samples (Table 3, Fig. 2d). Amphiboles are seen plotting in glaucophane, winchite, barroisite and hornblende fields (Fig. 3). The zoned amphiboles vary from glaucophane to magnesio-hornblende and show composition variation of $\mathrm{Fe}^{+3} /\left(\mathrm{Fe}^{+3}+\mathrm{Al}^{\mathrm{vi}}\right)$ from 0.054 to $0.518, \mathrm{Mg} /\left(\mathrm{Mg}+\mathrm{Fe}^{+2}\right)$ show variation from 0.762 to 0.580 , while $\mathrm{Na} /(\mathrm{Na}+\mathrm{Ca})$ ratios show variation from 0.966 to 0.356 (Table 3). There is complete substitution between $\mathrm{Al}^{\mathrm{vi}}$ and $\mathrm{Fe}^{+3}$ in $\mathrm{M} 2$ site in amphiboles.

The micas in these eclogites are paragonite and phengite along with retrograde biotite. The phengite has high $\mathrm{Si}$ 
Table 2: EPMA data showing the zoning in garnet from the eclogites (Sample No. RH-46) from Tso-Morari region, Ladakh

\begin{tabular}{|c|c|c|c|c|c|c|c|c|}
\hline & Core & $>$ & $>$ & $>$ & $>$ & $>$ & 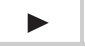 & $\operatorname{Rim}$ \\
\hline & \multicolumn{8}{|c|}{ Line analyses from Fig. $2 \mathrm{a}$} \\
\hline & 1 & 2 & 3 & 4 & 5 & 6 & 7 & 8 \\
\hline $\mathrm{SiO}_{2}$ & 37.74 & 38.04 & 37.34 & 37.46 & 37.70 & 38.10 & 37.64 & 39.09 \\
\hline $\mathrm{Al}_{2} \mathrm{O}_{3}$ & 20.95 & 21.17 & 20.53 & 21.05 & 21.30 & 21.16 & 21.01 & 21.64 \\
\hline $\mathrm{FeO}$ & 28.72 & 29.41 & 29.72 & 29.33 & 29.63 & 28.82 & 28.30 & 27.38 \\
\hline $\mathrm{MnO}$ & 0.45 & 0.36 & 0.39 & 0.45 & 0.43 & 0.28 & 0.44 & 0.24 \\
\hline MgO & 3.10 & 3.56 & 3.59 & 3.99 & 4.45 & 5.17 & 5.20 & 5.64 \\
\hline $\mathrm{CaO}$ & 8.20 & 7.48 & 6.49 & 6.70 & 6.99 & 5.79 & 6.14 & 6.87 \\
\hline Total & 99.16 & 100.02 & 98.06 & 98.98 & 100.50 & 99.32 & 98.73 & 100.86 \\
\hline $\mathrm{Si}$ & 3.011 & 3.008 & 3.013 & 2.992 & 2.969 & 3.008 & 2.991 & 3.018 \\
\hline Al & 1.970 & 1.973 & 1.952 & 1.982 & 1.977 & 1.969 & 1.967 & 1.969 \\
\hline $\mathbf{F e}$ & 1.916 & 1.945 & 2.005 & 1.959 & 1.952 & 1.903 & 1.880 & 1.768 \\
\hline Mn & 0.030 & 0.024 & 0.027 & 0.030 & 0.029 & 0.019 & 0.030 & 0.016 \\
\hline $\mathbf{M g}$ & 0.369 & 0.420 & 0.432 & 0.475 & 0.523 & 0.609 & 0.616 & 0.649 \\
\hline $\mathrm{Ca}$ & 0.701 & 0.634 & 0.561 & 0.573 & 0.590 & 0.490 & 0.523 & 0.568 \\
\hline $\mathbf{X}_{\mathrm{Fe}}$ & 0.635 & 0.643 & 0.663 & 0.645 & 0.631 & 0.630 & 0.617 & 0.589 \\
\hline $\mathbf{X}_{\mathbf{M n}}$ & 0.010 & 0.008 & 0.009 & 0.010 & 0.009 & 0.006 & 0.010 & 0.005 \\
\hline $\mathbf{X}_{\mathrm{Mg}}$ & 0.122 & 0.139 & 0.143 & 0.156 & 0.169 & 0.201 & 0.202 & 0.216 \\
\hline $\mathbf{X}_{\mathrm{Ca}}$ & 0.232 & 0.210 & 0.185 & 0.189 & 0.191 & 0.162 & 0.171 & 0.189 \\
\hline
\end{tabular}

content, 3.371 a.f.u (Table 1). Phengites are characterized by high $\mathrm{X}_{\text {cel }}(0.46)$, while the paragonite in these rocks have high $\mathrm{X}_{\text {mus }}>0.9$. The biotite is rich in $\mathrm{X}_{\text {eas }}$ and $\mathrm{X}_{\mathrm{phl}}$. Retrogressive replacement of rutile by mantling ilmenite is observed in these rocks (Fig. 2b). Zoisite and clinozoisite, the polymorph of $\mathrm{Ca}_{2} \mathrm{Al}_{3} \mathrm{Si}_{3} \mathrm{O}_{12}(\mathrm{OH})$ are common rock forming minerals in these rocks. According to Poli and Schmidt (1998) in natural rocks where Fe is present, orthorhombic zoisite is typical for eclogite facies whereas clinozoisite or epidote occurs at low to intermediate pressure conditions. The other accessory minerals include $\mathrm{Mg}-\mathrm{Fe}$ chlorite, dolomite, kyanite, euhedral magnetite, apatite, quartz and zircon.

\section{DISCUSSION}

The geochemical studies carried out by the authors (Rameshwar Rao and Rai 2006) suggested that, the eclogites have generated in an intra-continental rift predating the Himalayan subduction and collision event, and that they represent the present-day surface exposure of the deep mantle plumes with an enrichment of OIB component. The protoliths of these rocks are basic igneous rocks, Fe-rich type such as ferro-gabbros and basalts with basic mineral like plagioclase, clinopyroxene and Ti-magnetite, and are derived by the partial melting of peridotite (lherzolites) at depths greater than $60-80 \mathrm{~km}$. The rocks of broadly basaltic chemistry attain
Table 3: EPM data of amphibole showing chemical variation from glaucophane cores to magnsio hornblende rims in eclogites (Sample no. RH-353) from Tso-Morari region, Ladakh

\begin{tabular}{|c|c|c|c|c|c|c|c|c|}
\hline & 1 & 2 & 3 & 4 & 5 & 6 & 7 & 8 \\
\hline & $\begin{array}{l}\text { Line analyses } \\
\text { from Fig. 2d }\end{array}$ & & & & & & & \\
\hline & Core & $\nabla$ & 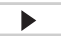 & $\nabla$ & 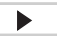 & $\nabla$ & 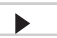 & Rim \\
\hline $\mathrm{SiO}_{2}$ & 58.57 & 58.30 & 58.44 & 58.21 & 58.28 & 53.41 & 50.13 & 47.68 \\
\hline $\mathrm{Al}_{2} \mathrm{O}_{3}$ & 11.17 & 10.96 & 10.80 & 10.51 & 10.57 & 9.10 & 8.42 & 8.78 \\
\hline $\mathrm{TiO}_{2}$ & 0.05 & 0.02 & & 0.06 & 0.04 & 0.06 & 0.15 & 0.07 \\
\hline $\mathrm{FeO}$ & 7.29 & 10.68 & 10.36 & 9.84 & 10.71 & 15.22 & 17.12 & 18.62 \\
\hline MnO & & 0.10 & 0.05 & 0.02 & & 0.12 & 0.19 & 0.12 \\
\hline MgO & 11.51 & 10.54 & 10.73 & 10.82 & 10.95 & 10.13 & 10.17 & 9.88 \\
\hline $\mathrm{CaO}$ & 0.46 & 0.80 & 0.83 & 0.92 & 1.28 & 5.11 & 7.38 & 9.20 \\
\hline $\mathrm{Na}_{2} \mathrm{O}$ & 7.25 & 7.03 & 6.86 & 6.57 & 6.63 & 4.73 & 3.69 & 2.81 \\
\hline $\mathrm{K}_{2} \mathrm{O}$ & 0.04 & 0.01 & 0.03 & & 0.02 & 0.09 & 0.20 & 0.20 \\
\hline Total & 96.34 & 98.44 & 98.10 & 96.95 & 98.48 & 97.97 & 97.45 & 97.36 \\
\hline $\mathrm{FeO}$ & 6.42 & 7.41 & 7.05 & 6.75 & 7.04 & 10.62 & 11.70 & 12.76 \\
\hline $\mathrm{Fe}_{2} \mathrm{O}_{3}$ & 0.97 & 3.63 & 3.68 & 3.43 & 4.08 & 5.11 & 6.02 & 6.51 \\
\hline $\mathrm{Si}$ & 8.012 & 7.898 & 7.924 & 7.764 & 7.888 & 7.538 & 7.257 & 7.005 \\
\hline $\mathbf{A \mathbf { I } ^ { i v }}$ & & 0.102 & 0.076 & 0.036 & 0.112 & 0.462 & 0.743 & 0.995 \\
\hline$A l^{v i}$ & 1.801 & 1.648 & 1.650 & 1.659 & 1.574 & 1.051 & 0.693 & 0.525 \\
\hline $\mathbf{T i}$ & 0.005 & 0.002 & & 0.006 & 0.004 & 0.006 & 0.016 & 0.008 \\
\hline $\mathrm{Fe}^{+2}$ & 0.734 & 0.840 & 0.799 & 0.773 & 0.797 & 1.254 & 1.417 & 1.568 \\
\hline $\mathrm{Fe}^{+3}$ & 0.100 & 0.370 & 0.375 & 0.353 & 0.416 & 0.543 & 0.656 & 0.720 \\
\hline Mn & & 0.011 & 0.006 & 0.002 & & 0.014 & 0.023 & 0.015 \\
\hline Mg & 2.347 & 2.129 & 2.169 & 2.207 & 2.209 & 2.131 & 2.195 & 2.164 \\
\hline $\mathrm{Ca}$ & 0.067 & 0.116 & 0.121 & 0.135 & 0.186 & 0.773 & 1.145 & 1.448 \\
\hline $\mathrm{Na}$ & 1.923 & 1.847 & 1.804 & 1.743 & 1.740 & 1.294 & 1.036 & 0.800 \\
\hline $\mathrm{K}$ & 0.007 & 0.002 & 0.005 & & 0.003 & 0.016 & 0.037 & 0.037 \\
\hline M4 site & 0.007 & 0.002 & 0.004 & & 0.003 & 0.083 & 0.217 & 0.286 \\
\hline $\mathrm{Fe}^{+3} /\left(\mathrm{Fe}^{+3}+\mathrm{Al}^{\mathrm{vi}}\right)$ & 0.053 & 0.183 & 0.185 & 0.175 & 0.209 & 0.272 & 0.486 & 0.578 \\
\hline $\mathrm{Mg} /\left(\mathrm{Mg}^{2}+\mathrm{Fe}^{+2}\right)$ & 0.762 & 0.717 & 0.731 & 0.741 & 0.734 & 0.629 & 0.608 & 0.580 \\
\hline $\mathrm{Na} /(\mathrm{Na}+\mathrm{K})$ & 0.966 & 0.941 & 0.937 & 0.928 & 0.903 & 0.626 & 0.475 & 0.356 \\
\hline
\end{tabular}

eclogite facies (garnet + pyroxene \pm quartz) on the disappearance of plagioclase. The attainment of high pressure metamorphism by these rocks is evident from the relatively high Si contents (3.371 a.f.u.; Table 1) of phengite (Massonne and Schreyer 1987), the presence of rutile besides almandine-rich garnet and omphacite (Bohlen et al. 1983). The eclogites with their almandine garnet, $\mathrm{Fe}^{+3}$ rich omphacite, plus rutile, magnetite, ilmenite along with other observed mineral assemblage can also be equated to the class of $\mathrm{Fe}-\mathrm{Ti}$ rich Superferrain eclogites derived from $\mathrm{Fe}-\mathrm{Ti}$ gabbros and basalts described by Mottana et al. (1990).

Since the rate of mineral reactions in the eclogites, both during eclogite formation and retrogression, being slow compared with the rates of change in $\mathrm{P}$ and $\mathrm{T}$, they preserve textures (Fig. 2) which can be used as tool to unravel the metamorphic history of these rocks. As a result of this, in well-preserved eclogite samples under study the reaction textures testify three main metamorphic stages: (i) an eclogite stage with late blueschist facies metamorphism, (ii) a medium-pressure amphibolite facies stage, and (iii) a lowpressure amphibolite to greenschist facies stage. From the textures observed, zoning in minerals and mineral inclusions in garnet, the following paragenesis of minerals can be inferred. The primary minerals of protoliths are magnetite, apatite, rutile, zircon, clinopyroxene, plagioclase and paragonite. 

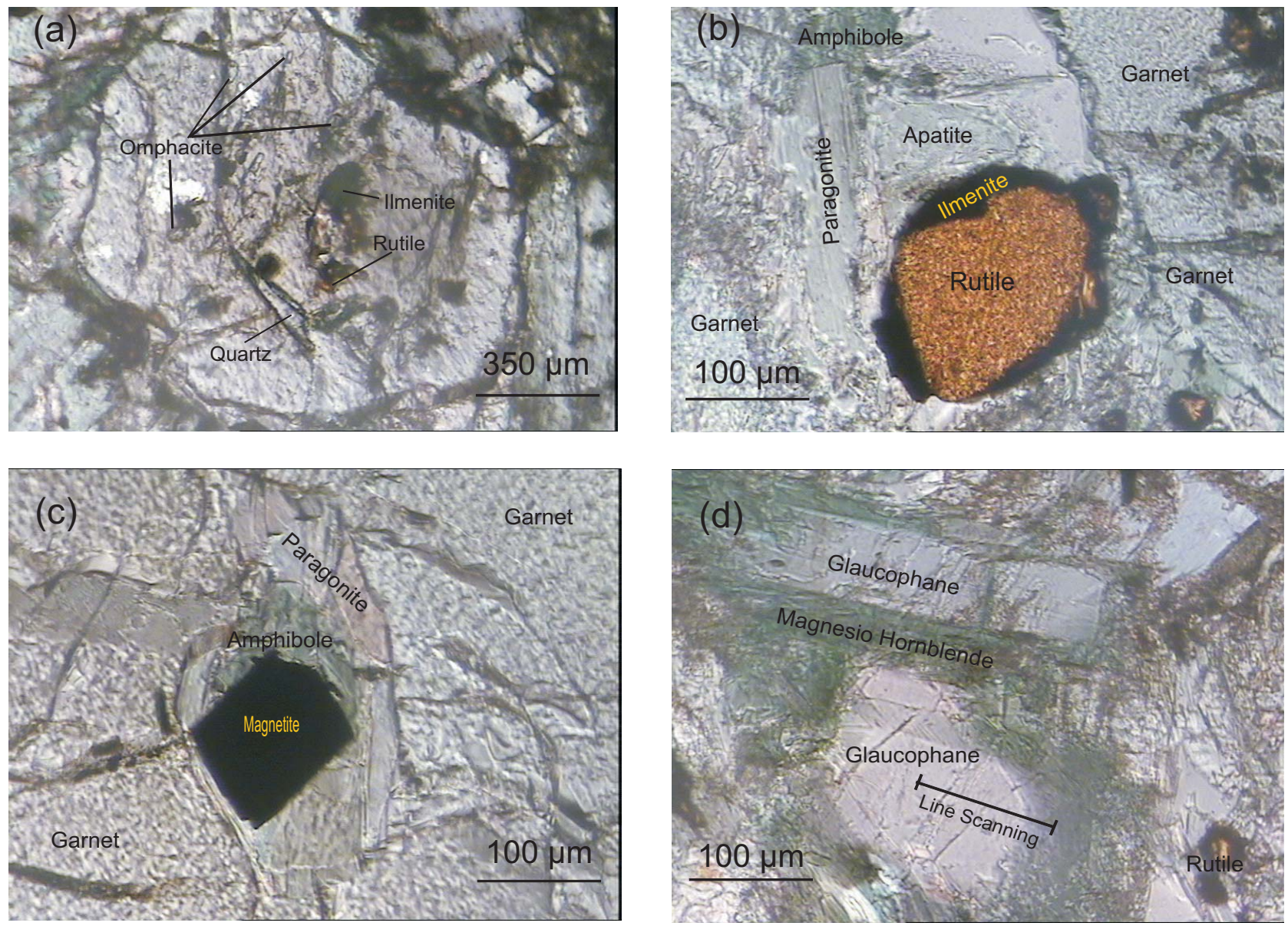

Fig. 2: (a-c) Mineral inclusions in garnet porphyroblast in eclogites from Tso-Morari region, Ladakh. The point analyses of minerals observed are given in Table 4. (d) Amphibole showing chemical zoning in eclogites from Tso-Morari region, Ladakh. The line analyses represented in figure from core to rim of amphibole are given in Table 3.

In the eclogites the textures of replacement of omphacite by plagioclase-diopside symplectite and replacement of omphacite by plagioclase-amphibole are observed. The plagioclase of igneous protoliths on metamorphism gives omphacite + quartz + zoisite, while clinopyroxene gives Naclinopyroxene + quartz. This is reflected in the omphacite composition, wherein omphacite shows increase in $\mathrm{Al}$ and $\mathrm{Na}$ and decrease of $\mathrm{Mg}$ and $\mathrm{Fe}$ from core to rim (Table 1). This explains the decrease of plagioclase and also becoming more sodic, until the albite component begins to react with pyroxenes to generate omphacite during eclogite formation. The outgoing of plagioclase can be represented by the reaction albite + pyroxene $=$ omphacite + quartz. The process involves the replacement of $\mathrm{Ca}, \mathrm{Mg}, \mathrm{Fe}$ in pyroxene by $\mathrm{Na}$ and Al in plagioclase during HP metamorphism of metabasics. The other possible reason could be that, during increase $\mathrm{P}$ and $\mathrm{T}$, the breakdown of paragonite will enhance the $\mathrm{Jd}$ content in the clinopyroxene phase, consequently clinopyroxene not only becomes omphacite but approaches the ideal composition. The incoming of garnet could be a result of enstatite + anorthite $=$ garnet + diopside + quartz . The omphacite pyroxenes along with garnet are transformed

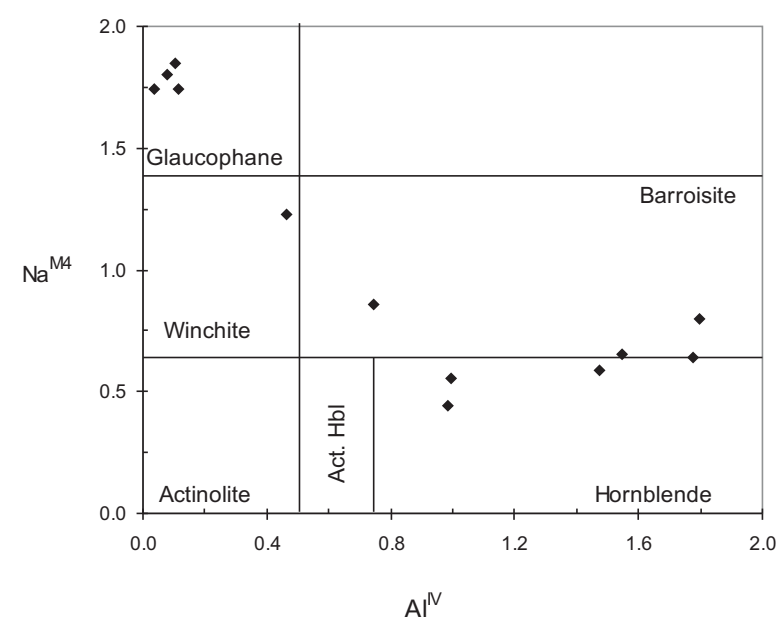

Fig. 3: Plot of $\mathrm{Al}^{\mathrm{iv}} \mathrm{vs} \mathrm{Na}^{\mathrm{M} 4}$ of amphibole from Tso-Morari region, Ladakh, showing its variation from glaucophane to hornblende, developed during the different stages of retrogressive metamorphism of eclogites to greenschist facies metamorphism 


\section{Rameshwar Rao and Hakim Rai}

Table 4: EPMA data of minerals occurings as inclucions in garnet porphryoblasts of eclogits from Tso-Morari region, Ladak

\begin{tabular}{|c|c|c|c|c|c|c|c|c|c|c|}
\hline & Garnet & Amphibole & \multirow{3}{*}{$\begin{array}{c}\text { Magnetite } \\
3 \\
3\end{array}$} & \multirow{3}{*}{$\begin{array}{c}\text { Paragonite } \\
\\
4\end{array}$} & Omphacite & Amphinbole & \multirow{3}{*}{$\begin{array}{c}\text { Paragonite } \\
\mathbf{3} \\
3\end{array}$} & \multirow{3}{*}{\begin{tabular}{|c|} 
Apatite \\
\\
\end{tabular}} & \multirow{3}{*}{$\begin{array}{c}\text { Rutile (C) } \\
- \\
5\end{array}$} & \multirow{3}{*}{$\begin{array}{c}\text { Ilmenite( R) } \\
6\end{array}$} \\
\hline & \multicolumn{2}{|c|}{ Point analysis (Fig. 1c) } & & & \multicolumn{2}{|c|}{ Point analysis (Fig. 1b) } & & & & \\
\hline & 1 & 2 & & & 1 & 2 & & & & \\
\hline $\mathrm{SiO}_{2}$ & 37.63 & 41.24 & 0.05 & 45.99 & 54.25 & 44.51 & 46.84 & 0.04 & 0.06 & 0.99 \\
\hline $\mathrm{Al}_{2} \mathrm{O}_{3}$ & 20.17 & 15.59 & 0.18 & 37.89 & 11.15 & 15.31 & 37.43 & & 0.01 & 0.35 \\
\hline $\mathrm{TiO}_{2}$ & 0.06 & 0.40 & 0.07 & & 0.06 & 0.28 & 0.19 & 0.02 & 99.07 & 55.76 \\
\hline FeO & 32.51 & 16.65 & 89.72 & 1.65 & 6.78 & 13.04 & 1.05 & 0.17 & 0.25 & 36.80 \\
\hline MnO & 1.02 & 0.11 & & 0.05 & 0.13 & 0.04 & & 0.19 & & 0.01 \\
\hline MgO & 3.35 & 9.60 & & 0.40 & 7.80 & 10.72 & 0.51 & 0.01 & & 0.13 \\
\hline $\mathrm{CaO}$ & 5.27 & 7.46 & 0.05 & 0.21 & 11.33 & 8.66 & 0.30 & 55.29 & 0.02 & 0.08 \\
\hline $\mathrm{Na}_{2} \mathrm{O}$ & 0.04 & 5.24 & 0.02 & 7.67 & 7.56 & 4.25 & 7.51 & 0.08 & 0.03 & 0.20 \\
\hline $\mathrm{K}_{2} \mathrm{O}$ & & & & 0.22 & 0.01 & 0.01 & 0.21 & & & \\
\hline $\mathbf{P}_{2} \mathbf{O}_{5}$ & & & & & & & & 42.86 & & \\
\hline \multirow[t]{2}{*}{ Total } & 100.05 & 96.29 & 90.09 & 94.08 & 99.07 & 96.82 & 94.04 & 98.66 & 99.44 & 94.32 \\
\hline & $12(\mathrm{O})$ & $23(\mathrm{O})$ & $4(\mathrm{O})$ & $11(\mathrm{O})$ & $6(\mathrm{O})$ & $23(\mathrm{O})$ & $11(\mathrm{O})$ & $26(\mathrm{O})$ & $2(\mathrm{O})$ & $3(\mathrm{O})$ \\
\hline $\mathbf{S i}$ & 3.016 & 6.238 & 0.003 & 2.997 & 1.970 & 6.527 & 3.039 & 0.007 & 0.001 & 0.025 \\
\hline Al & 1.905 & 2.779 & 0.011 & 2.911 & 0.477 & 2.646 & 2.862 & & & 0.011 \\
\hline Ti & 0.004 & 0.046 & 0.003 & & 0.002 & 0.031 & 0.009 & 0.003 & 0.997 & 1.069 \\
\hline $\mathrm{Fe}$ & 2.179 & 2.106 & 3.968 & 0.090 & 0.206 & 1.599 & 0.057 & 0.026 & 0.003 & 0.784 \\
\hline Mn & 0.069 & 0.014 & & 0.003 & 0.004 & 0.005 & & 0.030 & & \\
\hline Mg & 0.400 & 2.165 & & 0.039 & 0.422 & 2.344 & 0.049 & 0.003 & & 0.005 \\
\hline $\mathrm{Ca}$ & 0.453 & 1.209 & 0.003 & 0.015 & 0.441 & 1.361 & 0.021 & 11.027 & & 0.002 \\
\hline $\mathrm{Na}$ & 0.006 & 1.539 & 0.002 & 0.969 & 0.533 & 1.210 & 0.946 & 0.029 & 0.001 & 0.010 \\
\hline $\mathbf{K}$ & & & & 0.018 & & 0.002 & 0.017 & & & \\
\hline $\mathbf{P}$ & & & & & & & & 6.752 & & \\
\hline Leake's & & Ferro & & & & Ferroan & & & & \\
\hline \multirow[t]{2}{*}{ Classification } & & Richerite & & & & Paragasite & & & & \\
\hline & & & & & & $\mathrm{Hbl}$ & & & & \\
\hline
\end{tabular}

to complex aggregates of zoned amphiboles and symplectic of albite + amphibole + dolomite + quartz during the subsequent retrogressive stages of metamorphism.

Considering the association of glaucophane in eclogites, some authors mention glaucophane (actually a crossite) to be present in equilibrium (Pognate et al. 1988) with garnet + omphacite + rutile and others consider it to be a late or post-eclogite, phase grown by re-equilibration (Godard et al. 1981; Ernst and Dal 1978) under declining physical conditions. It is observed that in eclogites the earlier blueschist facies stage minerals such as crossite do not occur as fine-grained inclusions within garnet. However, during growth stage of garnet, they show the inclusions of ferroricherite or ferroan-paragasitic hornblende (Table 4 and Figs. $2 \mathrm{~b}$ and $2 \mathrm{c}$ ) suggesting glaucophane to be of late eclogite facies stage, probably involving reactions such as garnet + omphacite + paragonite $=$ glaucophane + clinozoisite and albite + paragonite $=$ glaucophane. Black (1977) studying the progressive metamorphism of glaucophane schists to eclogite from New Caledonia, found that calcic amphibole changes progressively from actinolite to barroisitehornblende with increasing metamorphic grade. Instead in the eclogites, the amphibole progressively changes from glaucophane to magnesio-hornblende (Table 3), which further suggests that progressive metamorphism of glaucophane schist to eclogite metamorphism is not observed. Thus it is interpreted that the eclogite facies stage is followed by the introduction of late stage blueschist facies minerals such as glaucophane, epidote and titanite, and that the glaucophane and titanite form in eclogites as pressures decrease during exhumation of the rocks.

The chemical variation in amphiboles is also indicative of the change in physical conditions during various stages of metamorphic history of eclogites. The chemical zoning in amphiboles, the minimum occupancy of 'A-site' in amphiboles for core composition of amphiboles (0.02-0.07; Table 3) corroborate with low temperature/high pressure conditions attained during eclogite facies metamorphism, and their progressive increase in 'A-site' occupancy towards rim (0.08-0.29; Table 3) suggest the increase of temperature and decrease of pressure that attained during the retrogressive stages of amphibole to greenschist facies metamorphism (Brown 1977; Holland and Richardson 1979). Further, the amphiboles in equilibrium with garnet and omphacite comprise both sodic and calcic (or sodic-calcic) members. Although it was originally interpreted as a product of 
retrograde metamorphism (Ernst and Dal 1978, Ernst 1981), this $\mathrm{Ca}-\mathrm{Na}$ amphibole of barroisite composition has been reinterpreted as being associated with glaucophane as a consequence of an equilibrium miscibility gap which closes at about $600{ }^{\circ} \mathrm{C}$ (Reynard and Balle'eve 1988). Barroisite and even winchite appear to replace glaucophane completely under higher $\mathrm{T}$ eclogite facies conditions (Maresch et al. 1982). The sudden compositional variation at the rims of amphiboles (Table 3) and also reflected in Fig. 2d could probably represent the equilibrium miscibility gap in amphiboles under study.

The final uplift and cooling are recorded by further deformation and retrograde recrystallization to epidoteamphibolite facies and ultimately greenschist facies assemblages. During the initial stage of garnet-epidote amphibolite stage, excess $\mathrm{Ca}$ is accommodated in epidote mineral (mostly zoisite, but also clinozoisite). Attendant with this recrystallization was the first development of barroisitichornblende and late of magnesio-hornblende at the expense of barroisite. At a later stage it resulted in the formation of dolomites, chlorites and biotites during the further retrogression to greenschist facies metamorphism. In the continuing retrograde development through amphibolite and greenschist facies, the fluids which were earlier rich in $\mathrm{CO}_{2}$ phase again become enriched in $\mathrm{H}_{2} \mathrm{O}$, due to the preferred incorporation of $\mathrm{CO}_{2}$ in dolomite at low temperature (Franz and Spear 1983). It also explains the presence of carbonate phase in these rocks. The late stage $\mathrm{H}_{2} \mathrm{O}$ fluids plays a very important role in the retrogression of eclogites to amphibolites, which can be expressed by the equation: garnet + omphacite $+\mathrm{H}_{2} \mathrm{O}=$ hornblende + plagioclase. Initially the formation of hornblende and plagioclase develop along the margins of the eclogites, and then grow progressively inwards, explaining the development of amphibolites of the Tso-Morari region.

\section{CONCLUSIONS}

Using observed textural and mineral paragenesis, and the stability relationship of both $\mathrm{Na}$ and $\mathrm{Na}-\mathrm{Ca}$ amphiboles it is summarized that the basic protoliths first underwent eclogite facies metamorphism, accompanied by a late stage blueschist facies metamorphism, and followed by recrystallization under epidote amphibolite and greenschist facies conditions. The significant retrogression of eclogite facies assemblages (via epidote-blueschist facies assemblage) to greenschist facies assemblages observed in the rocks under study suggests a more or less isothermal uplift path.

\section{ACKNOWLEDGEMENTS}

The authors thank Director, Wadia Institute of Himalayan Geology for providing facilities and giving permission to publish the paper. Anonymous reviewers are also acknowledged for their effort to improve the manuscript.

\section{REFERENCES}

Black, P. M., 1977, Regional high-pressure metamorphism in New Caledonian: phase equilibria in the Ouegoa district. Tectonophysics, v. 43, pp. 89-107.

Bohlen, S. R., Well, V. J., and Boettcher, A. L., 1983, Experimental investigations and geological applications of equilibria in the system $\mathrm{FeO}-\mathrm{TiO}_{2}-\mathrm{Al}_{2} \mathrm{O}_{3}-\mathrm{SiO}_{2}-\mathrm{H}_{2} \mathrm{O}$. Am. Min., v. 68, pp. 10491058.

Brown, E. H., 1977, The crossite content of Ca-amphibole as a guide to pressure of metamorphism. J. Petrol., v. 18, pp. 53-72.

de Sigoyer, J., Chavagnac, V., Blichert-Toft, J., Villa, I. M., Luais, B., Guillot, S., Cosca, M., and, Mascle, G., 2000, Dating the Indian continental subduction and collisional thickening in the northwest Himalaya: multichronology of the Tso-Morari eclogites, Geology, v. 28, pp. 487-490.

de Sigoyer, J., Guillot, S., Lardeaux, J. M., and Mascle, G., 1997, Glaucophane-bearing eclogites in the Tso-Morari dome (eastern Ladakh, NW Himalaya). Eur. J. Min., v. 9, pp. 1073- 1083.

Ernst, W. G., 1981, Petrogenesis of eclogites and peridotites from the Western and Ligurian Alps. Am. Min., v. 66, pp. 443-472.

Ernst, W. G. and Dal Piaz, G. V., 1978, Mineral paragenesis of eclogite rocks and relating mafic schists of the Piemonte ophiolite nappe, Breuil-St. Jacques area, Italian Western Alps, Am. Min., v. 63, pp. 621-640.

Franz, G. and Spear, F. S., 1983, High pressure metamorphism in siliceous dolomites from the central Tauern Window, Austria. Am. J. Sci., v. 283 (A), pp. 396-413.

Girard, M. and Bussy, F., 1999, Late Pan-African magmatism in Himalaya: new geochronological and geochemical data from the Ordovician Tso Morari metagranites (Ladakh, NW India). Schweiz. Min. Petrol. Mett., v. 79, pp. 399-418.

Godard, G., Kienast, J. R., and Lasnier, B., 1981, Retrogression development of glaucophane in some eclogites from 'massif Armoricain' (East of Nantes, France). Contrib. Mineral. Petrol., v. 78, pp. 126-135.

Guillot, S., de Sigoyer, Lardeaux, J. M., and Mascle, G., 1997, Eclogitic metasediments from the Tso-Morari area (Ladakh, Himalaya): evidence for continental subduction during IndiaAsia convergence. Contrib. Mineral.Petrol., v. 28, pp. 197- 212.

Holland, T. J. B. and Richardson, S. W., 1979, Amphibole zonation in metabasites as a guide to evolution of metamorphic conditions. Contrib. Mineral. Petrol., v. 70, pp. 143-148.

Islam, R., Rameshwar Rao, D., Gururajan, N. S., Hakim Rai, and Khanna, P. P., 2006, Geochemistry and petrogenesis of granitoids of Tso-Morari Crystalline complex, Ladakh, India. J. Geol. Soc. India, v. 65, pp. 325-334.

Jain, A. K., Singh, A., Manickavasagam, R. M., Joshi, M., and Verma, P. K., 2003, HIMPROBE Programme: integrated studies on geology, petrology, geochronology and geophysics of the trans-Himalaya and Karakoram. In: Mahadevan, T. M., Arora, B. R. and Gupta K. R., (Eds.), Indian Continental Lithosphere: Emerging Research Trends, Memiors Geol. Soc. India, v. 53, pp. 1-56.

Krogh, E. J., 1980, Geochemistry and petrology of glaucophane bearing eclogites and associated rocks from Sunnfjord, western Norway. Lithos, v. 13, pp. 355-380.

Krogh, E. J., 1982, Metamorphic evolution deduced from mineral inclusions and compositional zoning in garnets from Norwegian country-rock eclogites. Lithos, v. 15, pp. 305-321.

Maresch, W. V., Medenbach, O., and Rudolph, A., 1982, Winchite and the actinoliteglaucophane miscibility gap. Nature, v. 296, pp. 731-732. 


\section{Rameshwar Rao and Hakim Rai}

Massonne, H. J. and Schreyer, W., 1987, Phengite geobarometry based on the limiting assemblage with K-Feldspar, phlogopite and quartz. Contrib. Mineral. Petrol., v. 96, pp. 212-224.

Mottana, A., Carswell, D. A., Chopin, C. and Oberhansli, R., 1990, Eclogite facies mineral parageneses. In: Carswell, D. A. (Ed.), Eclogite Facies Rocks, Blackie, Glasgow and London, pp. 14-52.

Mukherjee, B. K. and Sachan, H. K., 2001, Discovery of coesite from Indian Himalaya: A record of ultra-high pressure metamorphism in Indian continental crust. Curr. Sci., v. 81, pp. 1358-1361.

Pognate, U., Talarico, F., and Benna, P., 1988, Incomplete blueschist re-crystallization in high-grade metamorphics from the Sesia-Lanzo unit (Vasario-Sparone subunit, western Alps): a case history of metastability. Lithos, v. 21, pp. 129-142.

Poli, S. and Schmidt, M.W., 1998, The high pressure stability of zoisite and phase relationships of zoisite-bearing assemblage. Contrib. Mineral. Petrol., v. 130, pp. 162-175.

Pouchou, J. L. and Pichoir, F., 1985, "PAP" ö(華Æ)? procedure for improved quantitative microanalysis. In Armstrong, J. T. (Ed.), Microbeam Analysis, pp. 104-106.

Rameshwar Rao, D. and Rai, H., 2002, Rb-Sr isotopic studies of Puga gneiss and Polokongka La granite from Tso-Morari region of Ladakh, India. Curr. Sci., v. 82 (9), pp. 1077-1079.

Rameshwar Rao, D. and Rai, H., 2006, Signatures of rift environment in the production of garnet-amphibolites and eclogites from Tso-Morari region, Ladakh, India: a geochemical study. Gondwana Res., v. 9, pp. 512-523.
Rameshwar Rao, D. and Subba Rao, T. V., 1996, AMPH: A program for calculating formulae and for assigning names to the amphibole group of minerals. Comp. and Geosci., v. 22 (8), pp. 931-933.

Reynard, B. and Balle'eve, M., 1988, Coexisting amphiboles in an eclogite from the Western Alps: new constraints on the miscibility gap between sodic and calcic amphiboles. Jour. Metamorphic Geology, v. 6, pp. 333-350.

Robinson, P., Spear, F. S., Schumacher, J. C., Laird, J., Klein, C., Evans, B. W., and Doolan, B. L., 1982, Phase relations of metamorphic amphiboles: Natural occurrence and theory. In: Veblen, D. R. and Ribbe, P. H., (Eds.), Amphiboles, 9B, pp. 1-228.

Sachan, H. K., Bodnar. R. J., Islam, R., Szabo, C. S. and Law, R. D., 1999, Exhumation history of Eclogites from the Tso-Morari crystalline complex in Eastern Ladakh: Mineralogical and fluid inclusion constraints. Jour. Geol. Soc. India, v. 53, pp. 181-190.

Schliestedt, M., 1990, Occurrence and stability conditions of lowtemperature eclogites. In: Carwell, D.A. (Ed.), Eclogite Facies Rocks, Blackie, Glasgow and London, pp. 160-179.

Singh, P. and Verma, P. K., 2006, Petrogenesis significance of Phengite and Biotite from the Ladakh UHP terrain, Northwest Himalaya. Indian J. Geochem., v. 21 (1), pp. 25-48.

Thakur, V. C. and Misra, D. K., 1984, Tectonic framework of Indus and Shyok Suture Zone in eastern Ladkah, northwest Himalaya. Tectonophysics, v. 101, pp. 207-220. 